\title{
Bacterial contributions to formation of transparent exopolymer particles (TEP) and seasonal trends in coastal waters of Sagami Bay, Japan
}

\author{
Kugako Sugimoto $^{1, *}$, Hideki Fukuda ${ }^{1}$, Mohammad Abdul Baki ${ }^{2}$, Isao Koike ${ }^{1}$ \\ ${ }^{1}$ Ocean Research Institute, University of Tokyo, 1-15-1 Minamidai, Nakano, Tokyo 164-8639, Japan \\ ${ }^{2}$ Graduate School of Environment and Information Sciences, Yokohama National University, 79-1 Tokiwadai, \\ Hodogaya, Yokohama 240-8501, Japan
}

\begin{abstract}
Seasonal trends in the bacterial formation of transparent exopolymer particles (TEP) were assessed in a seawater culture experiment using filtrate $(0.8 \mu \mathrm{m})$ obtained from surface water of Sagami Bay, Japan. An Alcian blue staining/colorimetric method was used to assess samples in both the presence and absence of metabolic inhibitors of bacteria. TEP formation was always negligible in the presence of metabolic inhibitors. However, the TEP accumulation rate ( $t=0$ to 1 ) associated with bacterial growth was high $\left(156.9 \pm 66 \mu \mathrm{g}\right.$ Gum Xanthan equivalents $\left.\mathrm{l}^{-1} \mathrm{~d}^{-1}\right)$ in September, October, and March, and low (0 $\pm 12.7 \mu \mathrm{g}$ Gum Xanthan equiv. $\left.\mathrm{l}^{-1} \mathrm{~d}^{-1}\right)$ from December to February, even for samples with large increases in bacterial numbers. The observed TEP accumulation rate without metabolic inhibitors was positively correlated with chlorophyll a concentration $(r=0.799, n=9)$, bacterial organic carbon production rate $(r=0.784, \mathrm{n}=9)$, and bacterial number $(\mathrm{r}=0.948, \mathrm{n}=9)$ in the field, indicating the importance of exudates from phytoplankton and probably from bacteria. During the months with high TEP formation rates, the bacterial TEP that formed in terms of carbon exceeded bacterial carbon utilization by 1 - to 2 -fold, suggesting an indirect process of bacterial TEP formation. Based on microscopic examinations of seawater cultures and field samples, the scavenging of TEP precursors by increased bacterial particles was important in the bacterial enhancement of high TEP formation in fall and early spring. These observations suggest the importance of bacteria as mediators of bacteria-associated TEP formation coupled to the supply of usable dissolved organic matter, including TEP precursors.
\end{abstract}

KEY WORDS: Alcian blue · Transparent exopolymer particles · TEP $\cdot$ Bacteria $\cdot$ Particle morphology

\section{INTRODUCTION}

Transparent exopolymer particles (TEP), which are polysaccharide particles stained by Alcian blue, influence the biogeochemical cycle of carbon in the ocean. TEP can assemble abiotically because of their sticky nature (Dam \& Drapeau 1995, Engel 2000). Their stickiness serves as glue to facilitate the aggregation between phytoplankton (Riebesell 1991) and bacteria (Alldredge et al. 1993) and the formation of 'marine snow' (Alldredge et al. 1993). Consequently, fixed organic carbon is exported as TEP sink from the euphotic zone to the ocean interior. This process may represent one of the necessary mechanisms for sedimentation in the ocean. Owing to the abundance of TEP and TEP precursors (Hong et al. 1997), as well as their unique functions, a better understanding of TEP production associated with planktonic communities in the upper ocean is essential for improving our knowledge of oceanic biogeochemical cycles.

Seasonal variations in TEP production have often been associated with phytoplankton variations, especially diatom blooms (Grossart \& Simon 1997, Passow et al. 2001). Given that TEP production is primarily 
controlled by the availability of nanometer-sized TEP precursors and that diatoms can produce these precursors in culture and under field conditions, diatoms have been considered the dominant organisms responsible for TEP production (Kiørboe \& Hansen 1993, Passow \& Alldredge 1994). Other factors such as the physiological state of phytoplankton (Passow \& Alldredge 1995a, Grossart et al. 2006), irradiance (Hong et al. 1997), and physical factors, including wind-stimulated shear (Grossart et al. 1998) and bubbling (Zhou et al. 1998), also influence TEP production.

Autotrophs, such as Phaeocystis sp. (Passow 2000) and macroalgae (Ramaiah et al. 2001), and heterotrophs, such as marine bacteria (Passow 2002a, Radic et al. 2003) and nanoflagellates (Passow 2000), can produce TEP. However, controversy exists regarding the importance of these organisms, especially the contribution of marine bacteria, to TEP formation in natural environments (Stoderegger \& Herndl 1999, Passow 2002a, Prieto et al. 2002). Bacteria release significant amounts of extracellular polysaccharides (EPS) in the form of capsules, films, and free exopolymers (Decho 1990, Cowen 1992, Shibata et al. 1997). Metabolically active bacteria constantly release capsular material to the surrounding water, in amounts equivalent to $25 \%$ of the respired carbon (Stoderegger \& Herndl 1998). Bacteria have unique roles in TEP dynamics, such as (1) the potential to function as nuclei by sticking to TEP precursors and (2) the enhancement of collisions among dissolved organic materials (DOM), possibly including TEP precursors, as a result of bacterial motility (Johnson \& Kepkay 1992). The sticky coating materials on bacteria allow the attachment of precursors (Van Loosdrecht et al. 1989) and the consequent formation of TEP. The encounter rate of bacteria with DOM can be influenced by shearing, surface coagulation (Johnson et al. 1986), and other collision mechanisms. Radic et al. (2003) found that bacterial TEP formation was enhanced under turbulent conditions, whereas Stoderegger \& Herndl (1999) found that fewer, but larger particles were produced under conditions of high turbulence. Nevertheless, the indirect roles of bacteria in TEP formation have not been extensively examined.

The aim of the present study was to extract and evaluate seasonal trends in the formation of TEP associated with bacterial growth by comparing predator-free bacterial assemblages obtained from coastal waters in samples with or without metabolic inhibitors. We found that bacteria enhanced the formation of TEP during the highly productive season, suggesting that bacteria-associated TEP formation depends on a combination of factors, which include the abundance of usable DOM as well as TEP pre- cursors and the amount of bacterial particles. In addition, the microscopic analysis revealed that bacteriadominated particles contribute greatly to the total TEP abundance.

\section{MATERIALS AND METHODS}

Sample collection and experimental procedure. Surface $(0 \mathrm{~m})$ seawater samples were collected once each month from August 2004 to April 2005 (Table 1) in coastal Sagami Bay, Japan $\left(35^{\circ} 9^{\prime} 30^{\prime \prime} \mathrm{N}\right.$, $\left.139^{\circ} 9^{\prime} 25^{\prime \prime} \mathrm{E}\right)$, where the deepest water was $120 \mathrm{~m}$. The samples were collected using a 51 Niskin sampler or a plastic bucket. Both sampling devices were washed with $\mathrm{HCl}$ and rinsed with Milli-Q water (Millipore) before use. For the incubation experiments, sample water was filtered with a Nuclepore filter (0.8 $\mathrm{\mu m}$ pore size: Whatman) to remove phytoplankton and bacterivores. Filtration was conducted within 6 to $7 \mathrm{~h}$ of sampling. Filtrates were stored in two $1 \mathrm{l}$ glass bottles that had been previously combusted at $550^{\circ} \mathrm{C}$ for $5 \mathrm{~h}$. Sodium azide $\left(\mathrm{NaN}_{3}\right)$, a respiratory chain inhibitor, with a final concentration of $0.02 \%$ $(\mathrm{w} / \mathrm{v})$, and antibiotics (streptomycin: final concentration, $25 \mathrm{U} \mathrm{ml}^{-1}$; penicillin: final concentration, $25 \mu \mathrm{g}$ $\mathrm{ml}^{-1}$ ) were added to one of the bottles to prevent bacterial activity. The 2 glass bottles were kept in a dark room at $20^{\circ} \mathrm{C}$ for 4 to $5 \mathrm{~d}$ under stagnant conditions. Duplicate samplings of filtrates were conducted at $24 \mathrm{~h}$ intervals under a flow hood. Filtered formaldehyde ( $2 \%$ final concentration) was added to preserve the samples until the analyses of TEP and bacterial abundance. The TEP accumulation rate was calculated as the difference between the TEP concentration at time $(t)=0$ (no incubation) and that at $t=1$ (1 $\mathrm{d}$ of incubation) or at $t=2$ (2 $\mathrm{d}$ of incubation), divided by the incubation time (1 or $2 \mathrm{~d}$ ).

To test for the possible interruption of TEP formation by $\mathrm{NaN}_{3}$ as a chelator of cations in seawater during

Table 1. Sampling dates, temperature, and salinity of water samples collected in Sagami Bay, Japan

\begin{tabular}{|lcc|}
\hline Sampling date & Temperature $\left({ }^{\circ} \mathrm{C}\right)$ & Salinity $(\%)$ \\
\hline August 12, 2004 & 28.0 & 31.3 \\
September 16, 2004 & 24.8 & 32.4 \\
October 15, 2004 & 21.5 & 27.6 \\
November 18, 2004 & 20.0 & 32.1 \\
December 17, 2004 & 18.3 & 34.5 \\
January 18, 2005 & 15.8 & 32.8 \\
February 17, 2005 & 15.1 & 35.0 \\
March 17, 2005 & 13.8 & 33.6 \\
April 14, 2005 & 15.0 & 34.1 \\
\hline
\end{tabular}


the incubation, Nuclepore $(0.2 \mu \mathrm{m}$ pore size) filtrates were obtained from Heterosigma carterae cultures (NEPCC 102, Canadian Center for the Culture of Microorganisms) grown in artificial seawater (ESAW) (Harrison et al. 1980). Autoclaved glass bottles were filled with the filtrates with or without both $\mathrm{NaN}_{3}$ and antibiotics, sealed, and rotated on a roller. The bottles were kept for $22 \mathrm{~h}$ at $4^{\circ} \mathrm{C}$ under dark conditions to minimize the bacterial influence. TEP concentrations were measured colorimetrically as described below. There was no significant difference between duplicate filtrates with and without inhibitors $(p>0.05$ : Student's $t$-test, $\mathrm{n}=4$ ).

Biological and chemical measurements. Bacteria were counted under an epifluorescence microscope ( $\times 1000$ : BX51; Olympus) after staining the nuclei with SYBR-Gold (Chen et al. 2001). Duplicate samples of $10 \mathrm{ml}$ (August to March) or $20 \mathrm{ml}$ (April) were filtered onto $0.2 \mu \mathrm{m}, 25 \mathrm{~mm}$ Nuclepore filters under constant vacuum $(<0.02 \mathrm{MPa})$ to make the slides. Two methods were used for the TEP analysis. The first method was a polysaccharide-specific dye-binding assay for the colorimetric measurement of TEP, using $100 \mathrm{ml}$ samples and $0.4 \mu \mathrm{m}, 25 \mathrm{~mm}$ Nuclepore filters (Passow \& Alldredge 1995b). This method was used for incubation experiments of filtered seawater $(0.8 \mu \mathrm{m})$ and for field samples $(0 \mathrm{~m})$ that were neither filtered nor incubated. The TEP concentrations were expressed in terms of Gum Xanthan equivalents (mg or $\mu \mathrm{g}$ Gum Xanthan equiv. $\mathrm{l}^{-1}$ ). The second method, used for field samples and the incubation experiment in April, employed microscopy $(\times 400)$ after staining. For the simultaneous observation of TEP morphology and bacterial assemblages, we applied a double-staining method using SYBR-Gold, which allowed stable observation even under UV light. The samples from the field (20 to $70 \mathrm{ml}$ ) and those from the April incubation experiment (20 ml) were first stained with SYBR-Gold (final concentration, $0.025 \%[\mathrm{v} / \mathrm{v}])$, then filtered onto $2.0 \mu \mathrm{m}$, $25 \mathrm{~mm}$ and onto $0.2 \mu \mathrm{m}, 25 \mathrm{~mm}$ Nuclepore filters, respectively, using the same procedure as for bacterial counting, and then stained with Alcian blue. The filtered samples were evaluated for TEP by a modified microscopy method (Logan et al. 1994). Pictures were taken with a camera (Olympus DP 70) connected to the microscope, and the particle areas associated with the areas stained by Alcian blue were measured on the images using Image Pro Plus software (Media Cybernetics). At least 30 TEP or 30 fields were measured for each slide. Duplicate and single samplings were conducted for the incubation experiment (April) and the field study, respectively.

Nutrient analyses were conducted using an autoanalyzer (AACS III; Bran + Luebbe) based on the methods described by Strickland \& Parsons (1972).
The detection limits of the auto-analyzer were $0.02 \mu \mathrm{M}$ for $\mathrm{PO}_{4}{ }^{3-}$ and $0.01 \mu \mathrm{M}$ for $\mathrm{NO}_{3}{ }^{-}$. Chlorophyll a (chl a) was extracted with N,N-dimethylformamide (Suzuki \& Ishimaru 1990) at $20^{\circ} \mathrm{C}$ for longer than $2 \mathrm{~d}$, and the chl a concentration was determined using a fluorometer (10-AU; Turner Designs; Holm-Hansen et al. 1965).

The bacterial organic carbon production rate was estimated from the incorporation rate of ${ }^{3} \mathrm{H}$-thymidine (Fuhrman \& Azam 1980). Subsamples from the surface water were incubated for $1 \mathrm{~h}$ at the in situ temperature $\left( \pm 2^{\circ} \mathrm{C}\right)$ in the dark. The thymidine incorporation rate was converted to bacterial production by assuming $3.9 \times 10^{17}$ cells mol$^{-1}$ (Ducklow 2000) and $15 \mathrm{fg} \mathrm{C} \mathrm{cell}^{-1}$ (Fukuda et al. 1998).

Statistical analysis. Pearson's correlation coefficient was used to test the correlation between the variables in Table 2. Student's $t$-test was used to test the influence of $\mathrm{NaN}_{3}$ as a chelator on TEP formation and the significance of the difference in TEP formation in the presence versus absence of biological inhibitors.

\section{RESULTS}

\section{Seasonal changes in biological parameters}

The water temperature was generally high in summer and low in winter and early spring, ranging from $28^{\circ} \mathrm{C}$ (August 2004) to $13.8^{\circ} \mathrm{C}$ (March 2005) (Table 1). The salinity showed little change and ranged between 27.6 and $35 \%$. Nitrate concentrations at $0 \mathrm{~m}$ varied widely, from undetectable $(<0.01 \mu \mathrm{M})$ in August to $17.6 \mu \mathrm{M}$ in October (Fig. 1a). The concentrations of nitrite and ammonium were $<2.57 \mu \mathrm{M}$ (October 2004) and 0.66 $\mathrm{\mu M}$ (April 2005), respectively, during the study and were generally much lower than those of nitrate (data not shown), with 2 exceptions: in August, the concentrations of the 3 forms of nitrogen (nitrate, $<0.01 \mu \mathrm{M}$; nitrite, $0.02 \mu \mathrm{M}$; ammonium, $<0.05 \mu \mathrm{M})$ were close to the detection limits; in September, the ammonium concentration was slighter higher $(0.13 \mu \mathrm{M})$ than nitrate $(0.09 \mu \mathrm{M})$. Phosphate concentrations ranged from $0.06 \mu \mathrm{M}$ in August to $0.43 \mu \mathrm{M}$ in January. The ratio of total inorganic $\mathrm{N}$ to $\mathrm{P}$ was lower than the Redfield ratio (16:1) only in summer.

Microscopy revealed large differences in the TEP abundance from August 2004 to April 2005 (9 mo) (Fig. 1b). TEP were most abundant in August $\left(172 \mathrm{~mm}^{2} \mathrm{l}^{-1}\right.$ ) and decreased to between 34.2 and $11.8 \mathrm{~mm}^{2} \mathrm{l}^{-1}$ in fall (September and November). The TEP abundance remained low throughout winter, with an average of $2.6 \mathrm{~mm}^{2} \mathrm{l}^{-1}$ and increased again in spring (March and April), reaching values similar to 
Table 2. Correlation analysis results for variables in the field and the incubation experiments: chlorophyll $a\left(\operatorname{chl} a_{1} \mu g l^{-1}\right) ;$ bacterial organic carbon production rate $\left(\mathrm{BP}, \mu \mathrm{g} \mathrm{Cl}^{-1} \mathrm{~d}^{-1}\right)$; bacterial growth $\left(\mathrm{BG}\right.$, cells $\left.\mathrm{ml}^{-1} \mathrm{~d}^{-1}\right)$; TEP area, the area of transparent exopolymer particles $\left(\mathrm{mm}^{2} \mathrm{l}^{-1}\right)$; bacterial number (No. cells $\left.\mathrm{ml}^{-1}\right)$; TEP accumulation rate $(t=0$ to 1$)$, calculated as the difference between the TEP values at $t=0$ and $t=1$ divided by $1 \mathrm{~d}\left(\mu \mathrm{g}\right.$ Gum Xanthan equiv. $\left.\mathrm{l}^{-1} \mathrm{~d}^{-1}\right)$; TEP accumulation rate $(t=0$ to 2$)$, calculated as the difference between the TEP values at $t=0$ and $t=2$ divided by $2 \mathrm{~d}\left(\mu \mathrm{g}\right.$ Gum Xanthan equiv. $\left.\mathrm{l}^{-1} \mathrm{~d}^{-1}\right)$. All analyses were based on $\mathrm{n}=9$. NS: not significant at $\mathrm{p}>0.05{ }^{*} \mathrm{p}<0.05 ;{ }^{* *} \mathrm{p}<0.01 i^{* * *} \mathrm{p}<0.001$

\begin{tabular}{|c|c|c|c|c|c|c|c|}
\hline & \multirow[t]{2}{*}{$\begin{array}{l}\text { Chl a } \\
\text { (field) }\end{array}$} & \multirow[t]{2}{*}{$\begin{array}{l}\text { BP rate } \\
\text { (field) }\end{array}$} & \multirow[t]{2}{*}{$\begin{array}{c}\text { BG } \\
\text { (culture) }\end{array}$} & \multirow[t]{2}{*}{$\begin{array}{l}\text { TEP area } \\
\text { (field) }\end{array}$} & \multirow[t]{2}{*}{$\begin{array}{l}\text { No. } \\
\text { (field) }\end{array}$} & \multicolumn{2}{|c|}{$\begin{array}{l}\text { TEP accumulation rate } \\
\text { (culture) }\end{array}$} \\
\hline & & & & & & $(t=0$ to 1$)$ & $(t=0$ to 2$)$ \\
\hline Chl a (field) & - & $\mathrm{r}=0.377 \mathrm{NS}$ & $\mathrm{r}=0.676^{*}$ & $\mathrm{r}=0.016 \mathrm{NS}$ & $\mathrm{r}=0.616 \mathrm{NS}$ & $\mathrm{r}=0.799^{* *}$ & $\mathrm{r}=0.433 \mathrm{NS}$ \\
\hline $\mathrm{BP}$ rate (field) & & - & $\mathrm{r}=0.196 \mathrm{NS}$ & $\mathrm{r}=0.875^{* *}$ & $\mathrm{r}=0.808^{* *}$ & $\mathrm{r}=0.784^{*}$ & $\mathrm{r}=0.114 \mathrm{NS}$ \\
\hline BG (culture) & & & - & $\mathrm{r}=0.059 \mathrm{NS}$ & $\mathrm{r}=0.471 \mathrm{NS}$ & $\mathrm{r}=0.551 \mathrm{NS}$ & $\mathrm{r}=0.557 \mathrm{NS}$ \\
\hline TEP area (field) & & & & - & $\mathrm{r}=0.701^{*}$ & $\mathrm{r}=0.541 \mathrm{NS}$ & $\mathrm{r}=0.163 \mathrm{NS}$ \\
\hline No. (field) & & & & & - & $\mathrm{r}=0.948^{* * *}$ & $\mathrm{r}=0.309 \mathrm{NS}$ \\
\hline $\begin{array}{l}\text { TEP accumulation rate } \\
\text { (culture) } \\
(t=0 \text { to } 1) \\
(t=0 \text { to } 2)\end{array}$ & & & & & & - & $\begin{array}{c}\mathrm{r}=0.431 \mathrm{NS} \\
-\end{array}$ \\
\hline
\end{tabular}

those measured in fall (average, $24.5 \mathrm{~mm}^{2} \mathrm{l}^{-1}$ ). From December to April (5 mo), TEP levels were also analyzed by a colorimetric method and were expressed as $\mathrm{mg}$ of Gum Xanthan equiv. $\mathrm{l}^{-1}$ (Fig. 1b). The TEP concentration was highest in March $(0.25 \mathrm{mg}$ Gum Xanthan equiv. $\mathrm{l}^{-1}$ ) and lowest in February (0.05 mg Gum Xanthan equiv. $\mathrm{l}^{-1}$ ). The monthly trends were similar to those obtained under microscopic observation ( $\mathrm{r}=0.968, \mathrm{n}=5)$.

The chl a concentration also showed large seasonal variations (Fig. 1c) and was highest (15.1 $\mathrm{g} \mathrm{l}^{-1}$ ) in October, which was also the month with the highest concentration of nitrate. Chl a concentrations remained low in winter and increased again at the beginning of spring 2005. The highest chl a values were most often obtained at $0 \mathrm{~m}$ during all months except March, when the highest value occurred at a depth of $10 \mathrm{~m}$ (data not shown). Overall, the water used for the incubation experiments represented the highly productive layer of the field profiles.

The number of bacteria showed only small changes throughout the seasons, ranging from $2.0 \times 10^{6}$ to $4.2 \times$ $10^{5}$ cells ml ${ }^{-1}$ (Fig. 1c). However, a slight seasonal trend was observed, with lower values in winter and higher values in summer and spring.

The bacterial organic carbon production rate ranged from 0.1 to $4.8 \mu \mathrm{g} \mathrm{C} \mathrm{l}^{-1} \mathrm{~d}^{-1}$ (Fig. 1c). In August, the bacterial organic carbon production rate was high $(4.8 \mu \mathrm{g}$ $\mathrm{C}^{-1} \mathrm{~d}^{-1}$ ) and the chl a value was low $\left(3.26 \mu \mathrm{g} \mathrm{l}^{-1}\right)$, whereas the reverse relationship was observed in October. From November to the following April, bacterial production showed a seasonal trend similar to that of chl $a$, with lower values in winter and higher values in spring.

\section{Change in bacterial number and TEP concentration during incubation}

Bacterial growth without inhibitors generally showed a rapid increase early during incubation $(t=0$ to 1 or $t=0$ to 2 ) and a decrease toward the end of the experiment (Fig. 2). The highest initial concentration was $2.0 \times 10^{6}$ cells ml ${ }^{-1}$ in August, and the lowest was $2.3 \times 10^{5}$ cells $\mathrm{ml}^{-1}$ in January. However, in most of the filtrates containing inhibitors, the bacterial numbers either remained nearly constant or decreased slightly during incubation (Fig. 2). These results indicate that $\mathrm{NaN}_{3}$ and antibiotics restrained bacterial growth and allowed the observation of TEP formation with and without biological activities, including bacterial activity, for most of the months ( $p<0.05, n=8)$, with the exception of August.

The addition of metabolic inhibitors led to negligible changes in TEP concentrations in all experiments (Fig. 2). TEP concentrations remained between 0.02 and $0.14 \mathrm{mg}$ Gum Xanthan equiv. $\mathrm{l}^{-1}$ for the entire incubation period ( 4 to $5 \mathrm{~d}$ ). In contrast, TEP formation coupled with bacterial growth was observed in the experiments without inhibitors, except in winter (Fig. 2).

In fall (September and October) and early spring (March), abundant TEP formation was associated with the initial increase in bacterial numbers, despite decreases or the absence of distinct changes in bacterial numbers in the subsequent incubation days (Fig. 2). The maximum TEP formation, calculated as the maximum TEP concentration minus the initial TEP concentration, during these months ranged between 0.38 and 0.99 mg Gum Xanthan equiv. $1^{-1}$. Moderate TEP forma- 

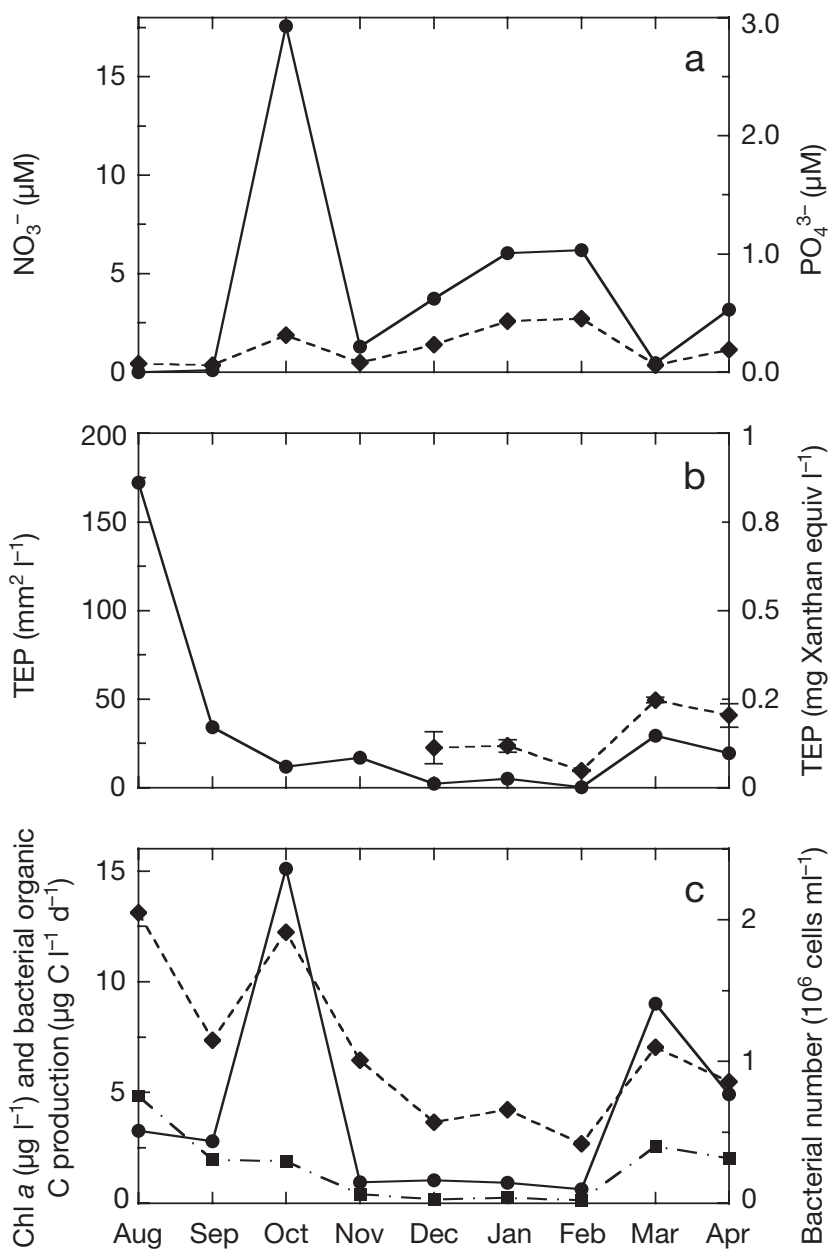

Fig. 1. (a) Monthly changes in surface $\mathrm{NO}_{3}{ }^{-}$(solid line) and $\mathrm{PO}_{4}{ }^{3-}$ (dashed line) in Sagami Bay, Japan; the $\mathrm{NO}_{3}{ }^{-}$value in August was $<0.01 \mu \mathrm{M}$, below the detection limit of the autoanalyzer. (b) Monthly changes in surface transparent exopolymer particles (TEP) abundance in Sagami Bay. TEP abundance was analyzed microscopically and expressed as area (solid line) for values from August to April and was analyzed spectrophotometrically and expressed as Gum Xanthan equivalents (dashed line) for values from December to April. Error bars for the TEP abundance measured spectrophotometrically indicate range. (c) Monthly changes in surface chlorophyll a (chl a) concentration (solid line), bacterial organic carbon production (dash-dotted line), and bacterial number (dashed line) in Sagami Bay

tion ( 0.15 to $0.22 \mathrm{mg}$ Gum Xanthan equiv. $\mathrm{l}^{-1}$ ) occurred in association with increased bacterial numbers, as seen in August, November, and April. The TEP concentration (0.26 mg Gum Xanthan equiv. $\left.\mathrm{l}^{-1}\right)$ and bacterial number $\left(3.2 \times 10^{6} \mathrm{cells} \mathrm{ml}^{-1}\right)$ for the April experiment reached a maximum at $t=2$ and dropped thereafter. From December to February, there was only a very small increase in TEP formation $(<0.15 \mathrm{mg}$ Gum Xanthan equiv. $\mathrm{l}^{-1}$ ) despite an increased bacterial count, which was a distinctive winter phenomenon.

\section{Microscopic observations of TEP during the incubation experiments}

To observe TEP formation at different stages of incubation, filtered samples were analyzed microscopically. The areas stained by Alcian blue on the micrographs were classified into 2 categories: (1) free TEP associated with negligible bacteria and (2) TEP associated with dense bacterial assemblages. Most of the Alcian blue-stainable particles observed at the early stage in the cultures without metabolic inhibitors were TEP with dense bacterial assemblages, and no free TEP were observed until $t=4$ (Fig. 3a). Based on the total area of the particles, $30 \%$ of the TEP were free and $70 \%$ were associated with dense bacterial assemblages at $t=4$. In the cultures with inhibitors, both free TEP and those associated with dense bacterial assemblages were observed throughout the entire incubation period, except at $t=0$ (Fig. 3b). However, free TEP as a percentage of the total particle area had a tendency to increase toward the end of the incubation time.

\section{Microscopic observations of TEP in the field samples}

Monthly changes in particles associated with TEP in the field at $0 \mathrm{~m}$ were monitored microscopically. In addition to the 2 categories of TEP aggregates observed in the culture experiment, TEP were also associated with larger amorphous particles and with phytoplankton in the field samples. The determination of the relative abundance in each category was semiquantitative because of the small sampling sizes. However, TEP particle association with dense bacterial assemblages was generally low in early fall (September and October) and early spring (March), and increased in winter (November and February) and mid-spring (April). Morphologically, the most abundant particles were TEP associated with either larger amorphous particles or with phytoplankton; the relative abundance of these 2 categories combined was roughly more than two-thirds of the total TEP during the observation period.

\section{DISCUSSION}

This study demonstrates clear seasonal trends in TEP formation associated with bacterial growth in coastal waters (Fig. 2). In the absence of inhibitors, the TEP concentrations increased in September and October, became low in winter, and increased moderately again in spring. Negligible TEP formation was detected spectrophotometrically in the filtrates containing bac- 

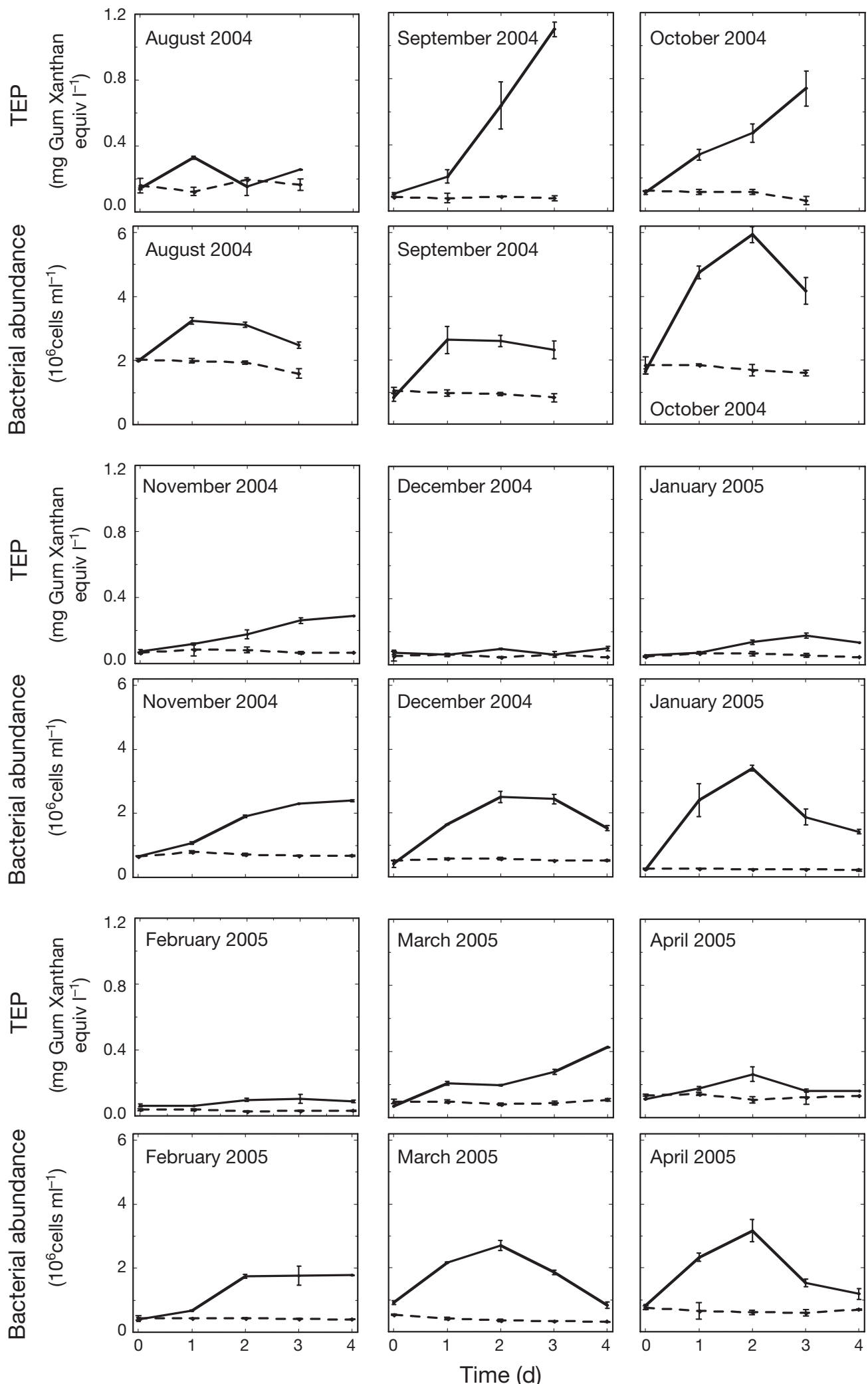

Fig. 2. Time-course variations of TEP concentration and the corresponding bacterial abundance in filtrates from natural seawater obtained from Sagami Bay surface waters $(0 \mathrm{~m})$. Dashed lines indicate filtrates with added sodium azide and antibiotics; solid lines indicate filtrates that did not receive these treatments. Each point is the average value of duplicate samples, and the error bars indicate range $\pm \mathrm{SD}$ 


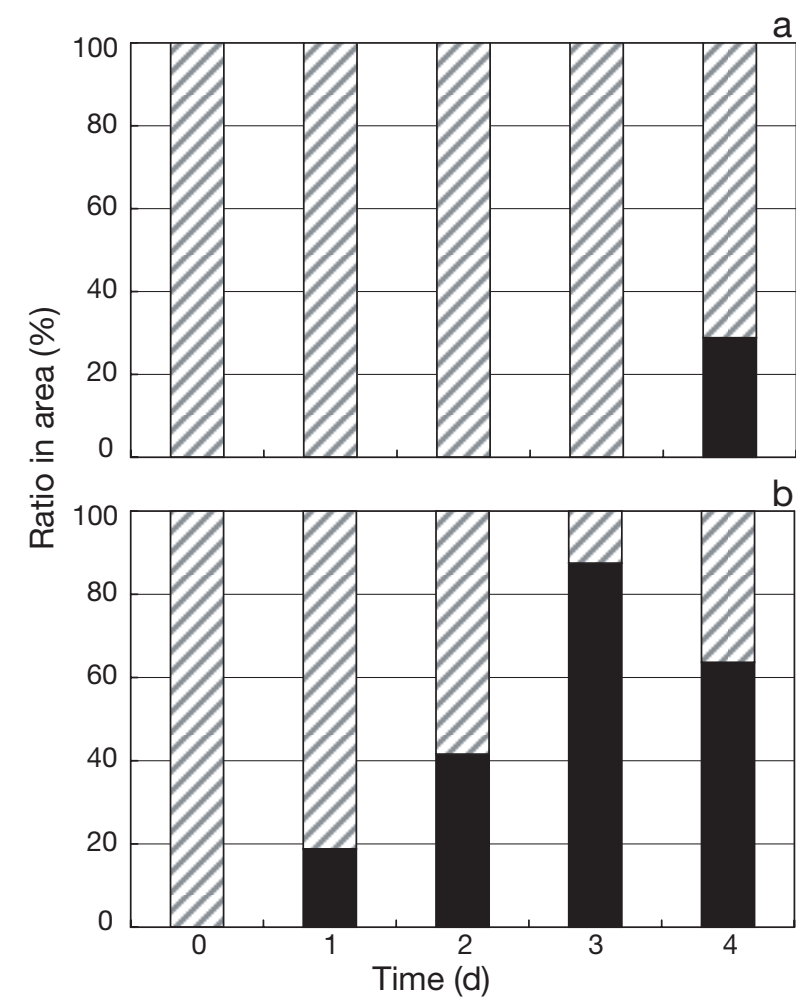

Fig. 3. Time-course variations in the percentage contribution of the 2 types of particles stained by Alcian blue in the incubation experiment samples using filtered natural surface seawater obtained from Sagami Bay in April 2005: (a) without an inhibitor and (b) with an inhibitor. Particles were categorized into 2 groups: TEP with dense bacterial assemblages (hatched portion) and free TEP associated with negligible bacteria (black portion). Each percentage was obtained by dividing the total particle area of each category by the sum of the total particle areas of the 2 categories

terial inhibitors; thus, TEP formation appears to be related to increases in bacterial abundance. The following discussion focuses on mechanisms that may have been important for bacterial contributions to TEP formation in the study area.

\section{Correlation between field parameters and bacterial TEP formation}

The analyses of incubation data and field parameters showed a good correlation between the TEP accumulation rate ( $t=0$ to 1 ) in the culture and the chl a concentration in the field $(r=0.799, n=9$; Table 2$)$, as well as the bacterial organic carbon production rate in the field ( $\mathrm{r}=0.784, \mathrm{n}=9$; Table 2$)$. Given that the availability of usable organic matter is a key factor for bacterial production, the above correlations suggest that TEP formation is related to the abundance of DOM, including TEP precursors, possibly mainly produced by phytoplankton. This is indirectly consistent with conventional reports of a good correlation between phytoplankton abundance and TEP abundance during blooms (Passow \& Alldredge 1994, Mari \& Kiørboe 1996), although there was no correlation between chl $a$ and TEP abundance at the site in the present study $(r=0.02, n=9)$. Most of the studies reporting a good correlation between TEP abundance and phytoplankton biomass have examined short-term bloom development. For long-term observation or the combination of bloom and non-bloom situations, as in this study, the above correlation may not be apparent. Other potential explanations for this incongruous relationship between chl $a$ and TEP abundance in the field include the timing of TEP production by phytoplankton (Penna et al. 1999) and the bacterial biodegradability and recalcitrance of TEP precursors (Grossart et al. 2006). The bacterial number in the field also had a positive correlation with the TEP accumulation rate ( $t=0$ to 1 ) in the culture experiments ( $\mathrm{r}=0.948, \mathrm{n}=9, \mathrm{p}=0.015)$.

\section{Possibility of TEP production by bacterial exudation}

The above correlation analyses suggest that the bacterial TEP accumulation rate is related not only to the availability of material for bacterial use, but also to the bacteria. Among the possibilities for bacterial contributions to TEP formation, we examined whether it was possible for bacteria to produce the measured amount of TEP using the available DOM. In the present study, the average TEP formation in samples with bacteria $<0.8 \mu \mathrm{m}$ (after filtration) was $1.77 \pm 1.6 \mathrm{fg}$ Gum Xanthan equiv. cell ${ }^{-1} \mathrm{~h}^{-1}(\mathrm{n}=9)$, which was calculated by dividing the increased TEP concentration by the average bacterial cell number during the initial period $(t=$ 0 to $1 \mathrm{~d}$ ). The values obtained during the productive season, such as $3.66 \mathrm{fg}$ Gum Xanthan equiv. cell ${ }^{-1} \mathrm{~h}^{-1}$ in March, were much higher than the reported mean TEP production rate $(0.11 \pm 0.03 \mathrm{fg}$ Gum Xanthan equiv. cell ${ }^{-1} \mathrm{~h}^{-1}$ ) in a seawater culture of natural bacterial assemblages obtained from the North Sea (Stoderegger \& Herndl 1999).

Based on literature reports of the TEP-to-carbon ratio (TEP-C $=0.75 \times$ Gum Xanthan equiv.; Passow $2002 b$ ) and the bacterial carbon production during the incubation experiment, the ratio of TEP-C to bacterial carbon production was calculated, assuming a bacterial cell carbon content of $15 \mathrm{fg}$ (Fukuda et al. 1998) and a carbon growth yield of $30 \%$ (Stoderegger \& Herndl 1998). In this calculation, the value 1 would represent the point at which the amount of carbon taken up by the bacteria equaled the amount of TEP$\mathrm{C}$ produced by the bacteria, a highly unlikely scenario. The average ratio of TEP-C:bacterial carbon 
was $0.89 \pm 0.87(\mathrm{n}=9)$ for the entire study period; however, the ratio increased to $1.37 \pm 0.6(n=6)$ when the low winter ratios (December, 0.14; January, 0.10; and February, 0.15) were excluded. The most extreme case occurred in August, giving a value of 2.29. As the above calculation was based on several assumptions in the conversion factor of Gum Xanthan equivalents to carbon obtained from diatom TEP and bacterial carbon contents, some uncertainties remain. Nevertheless, even if we were to use a higher range of bacterial carbon, i.e. $30 \mathrm{fg} \mathrm{C}$ cell $^{-1}$ (Vrede et al. 2002), the TEP-C:bacterial carbon production ratio during productive seasons would be $0.68 \pm 0.3(n=6)$, and the highest value would be 1.15 (August). Therefore, additional factors, such as the self assembly of TEP precursors coupled with bacterial growth, are necessary to explain the high bacterial TEP formation observed in our culture study.

\section{Indirect bacterial contributions to TEP formation}

To form suspended particles on the $0.4 \mu \mathrm{m}$ filter used in this study, small colloids such as TEP precursors must first collide and then remain stuck together to increase the particle size. Bacterial cell motility can increase the probability of collisions among colloidal materials (Johnson \& Kepkay 1992) by more frequently bumping particles of less than a few microns (O'Melia \& Tiller 1993), in addition to Brownian motion and convective diffusion of colloidal materials. Bacterial motility could create advective flow toward the bacteria and thereby increase the probability of collisions. This may have led to the high TEP formation that occurred in the incubation experiment under stagnant conditions.

A high concentration of colloidal materials seems necessary for bacterial motility to effectively create collisions and scavenge particles. High TEP formation occurred in our cultures during seasons in which large amounts of TEP precursors were expected to be available. Bacterial motility may work efficiently in such situations, although a quantitative evaluation of the effect would be difficult because of unknown parameters such as the numbers and sizes of the TEP precursors.

The interaction between the bacteria and TEP precursors can be mediated by neutral exopolymers produced by and attached to certain bacteria (Sutherland 1985), which have a lower repulsion than the negatively charged TEP precursors. To avoid filtering out small TEP precursors, neutrally coated bacteria could be introduced into the present incubation culture to serve as nuclei for attracting negatively charged TEP precursors, thus increasing the particle volume sufficiently to allow the precursors to be trapped on the filter. The attraction between neutrally coated bacteria and TEP precursors may be an additional mechanism of TEP formation in the presence of high numbers of bacteria.

Several mechanisms of TEP precursor self assembly (Stoderegger \& Herndl 1999, Passow 2000) have been proposed, including cation bridges (Kloareg \& Quatrano 1988) and hydrogen bonding (Chin et al. 1998) between TEP precursors. Precursor self assembly may explain the abundant TEP formation in the present incubation experiments. However, because there was no increase in TEP formation in the presence of biological inhibitors under spectrophotometric analyses, the self assembly of TEP precursors at the concentration and incubation period (up to between 4 and $5 \mathrm{~d}$ ) used in this study seemed to require some type of bacterial input.

Certain bacteria tend to form clusters, defined in the present study as TEP associated with dense bacterial assemblages in culture medium (Zobell 1941), whereas others tend to disperse (K. Sugimoto unpubl. data). Introducing such bacteria into the cultures could contribute to further TEP formation. Moreover, TEP precursors that form a gel seem to attract bacteria by offering attachment sites (Alldredge et al. 1993, Verdugo et al. 2004), consequently producing TEP-associated bacteria. Bacteria were reported to accumulate on 'invisible loci,' which were speculated to be TEP (Grossart et al. 2001). It is unclear whether bacteria serving as nuclei just accelerate the speed of the formation of TEP from precursors. Given the same initial concentration of TEP precursors, will the amount of TEP formation at equilibrium be the same for both filtered seawater with bacteria and that without bacteria? The significance of self assemblage of precursors and indirect contribution of bacteria on TEP formation has not yet been solved.

\section{Particle morphology in the incubation experiments and in the field}

Microscopic observations revealed the presence of free TEP associated with negligible bacteria, a typical form of precursor self assemblage, even in the samples with inhibitors during the April incubation experiment (Fig. 3b), which was not obviously detectable by the colorimetric assay. Free TEP were also observed in the samples without inhibitors at the end of the experiment ( $t=4$; Fig. 3a). However, free TEP were not observed during the early stages of the experiment without inhibitors, despite the relatively large increase in photometrically measured TEP. Most of the observed TEP were associated with dense bacterial assemblages, consistent with the possibility 


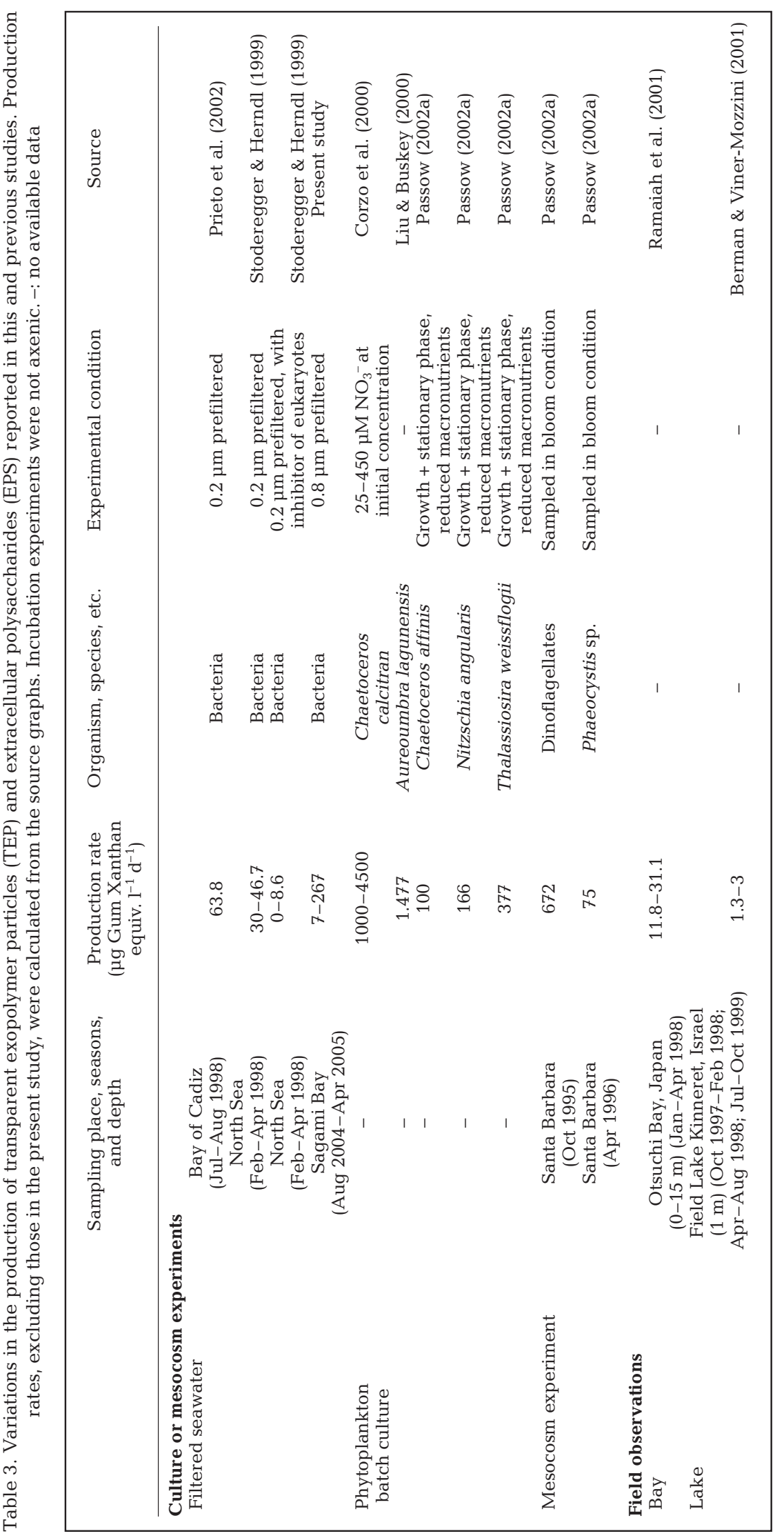

that bacteria contribute to TEP formation by serving as nuclei.

The microscopic analyses raised a concern regarding the discrepancy between the colorimetric and microscopic observations. TEP formation was barely visible spectrophotometrically in the samples with inhibitors, whereas particle morphology fluctuated in the microscopic observations. This incongruity may have been caused by different detection limits and different pore sizes of the filters used for the colorimetric $(0.4 \mu \mathrm{m})$ versus microscopic methods $(0.2 \mu \mathrm{m})$. The ability of the $0.2 \mu \mathrm{m}$ filter to capture TEP was 2.3-fold that of the $0.4 \mu \mathrm{m}$ filter (average of duplicate samples) with the spectrophotometric method and 1.5-fold that of the $0.4 \mu \mathrm{m}$ filter (duplicate samples of total particle area; $\mathrm{n}>200$ ) with the microscopic method, using natural seawater filtrates $(0.8 \mu \mathrm{m})$ obtained during a very productive season (K. Sugimoto unpubl. data).

Despite the discrepancy, the occurrence of free TEP at the late stage of incubation and the absence of free TEP at the early stage in untreated samples suggest that free TEP can form and remain free in water without active bacteria. Therefore, free TEP were observed throughout almost the entire incubation period, except at $t=0$, in the samples containing the bacterial inhibitor.

Interestingly, microscopic observations of field particle morphology revealed quite a large fraction of TEP with dense bacterial assemblages among the Alcian bluestainable particles, which was noticeable in winter and midspring (April). This is consistent with the results of the incubation experiment that showed a high percentage of TEP with dense bacterial assemblages in untreated samples. This fraction has not been sufficiently investigated despite its quantitative importance and possible function as a facilitator of particle formation. 


\section{Relevance of bacterial TEP formation}

In the incubation experiment, TEP formation associated with bacterial growth achieved a rate of $231 \mu \mathrm{g}$ Gum Xanthan equiv. $l^{-1} \mathrm{~d}^{-1}$ in October ( $t=0$ to 1$)$, which was much higher than the TEP production rates obtained from similar bacterial incubation experiments using water obtained from the North Sea $\left(16^{\circ} C_{i}\right.$ Stoderegger \& Herndl 1999) and the Bay of Cadiz (Prieto et al. 2002), i.e. 46.7 and $63.8 \mu \mathrm{g}$ Gum Xanthan equiv. $\mathrm{l}^{-1} \mathrm{~d}^{-1}$, respectively (Table 3 ). The October rate was even higher than the TEP production rates of the non-axenic cultured diatoms Chaetoceros affinis $\left(100 \mu \mathrm{g}\right.$ Gum Xanthan equiv. $\left.\mathrm{l}^{-1} \mathrm{~d}^{-1}\right)$ and Nitzschia angularis (166 $\mu \mathrm{g}$ Gum Xanthan equiv. $\mathrm{l}^{-1} \mathrm{~d}^{-1}$ ) grown on a $30 \%$ reduction of macronutrients (Passow 2002a), although the rate was only $15.6 \%$ (Liu \& Buskey 2000) and $23 \%$ (Corzo et al. 2000) of those for non-axenic $\mathrm{Au}$ reoumbra langunensis and Chaetoceros calcitran, respectively, grown on $25 \mu \mathrm{M} \mathrm{NO}_{3}^{-}$. TEP accumulation rates in Phaeocystis-dominated mesocosm experiments (Passow 2002a) were comparable to our October rates.

To estimate the bacterial potential of indirect and direct TEP formation in the field, standing stocks of TEP were divided by the TEP accumulation rates $(t=0$ to 2) obtained in the incubation experiments using the same month's seawater, from December to April. Between 9\% (December) and 37\% (April) of the standing stocks could be renewed daily by the sum of bacterial indirect and direct activity. Despite several assumptions, such as unchanged TEP availability in the field, bacterial indirect and direct TEP formation had a high potential to contribute to the field TEP dynamics. Therefore, the role of bacteria in TEP formation should be evaluated in both field and culture studies to better understand TEP formation under various environmental conditions.

\section{CONCLUSIONS}

We observed bacterium-associated TEP formation with seasonal variation in the filtered seawater. Specifically, the TEP accumulation rate during the first day showed a good correlation with the abundance of chl $a$ in pre-filtered water and with the bacterial organic carbon production rate in the field. This suggests that the abundance of TEP precursors, probably produced by phytoplankton, affect TEP formation by bacteria.

During productive seasons, abundant TEP formation occurred, but could not be explained only by physiological production by bacterial cells. Therefore, an indirect contribution of the bacterial population to TEP formation, such as bacteria acting to increase the attraction among TEP precursors, might be an important factor, at least during productive seasons.

The high ratio of TEP with dense bacterial assemblages to free TEP associated with negligible bacteria in our culture experiment, as shown by microscopic observation, indicates the importance of bacteria in the formation of TEP. This finding was not observable by the colorimetric method used here.

Acknowledgements. We thank Dr. M. Haro-Gary and Dr. D. G. Dye for their support and detailed comments on the manuscript. We also thank Dr. T. Kikuchi and the staff of the Graduate School of Environment and Information Sciences of Yokohama National University for help with the field observations. This study was supported by the DOBIS project (Dynamics of the Ocean Biosystems, MEXT Grant-in-Aid for Creative Basic Research 12NP0201).

\section{LITERATURE CITED}

Alldredge AL, Passow U, Logan BE (1993) The abundance and significance of a class of large, transparent organic particles in the ocean. Deep-Sea Res 40:1131-1140

Berman T, Viner-Mozzini Y (2001) Abundance and characteristics of polysaccharide and proteinaceous particles in Lake Kinneret. Aquat Microb Ecol 24:255-264

Chen F, Lu JR, Binder BJ, Liu YC, Hodoson RE (2001) Application of digital image analysis and flow cytometry to enumerate marine viruses stained with SYBR gold. Appl Environ Microbiol 67:539-545

Chin WC, Orellana MW, Verdugo P (1998) Spontaneous assembly of marine dissolved organic matter into polymer gels. Nature 391:568-571

Corzo A, Morillo JA, Rodriguez S (2000) Production of transparent exopolymer particles (TEP) in cultures of Chaetoceros calcitrans under nitrogen limitation. Aquat Microb Ecol 23:63-72

Cowen JP (1992) Morphological study of marine bacterial capsules: implications for marine aggregates. Mar Biol 114:85-95

Dam HG, Drapeau DT (1995) Coagulation efficiency, organicmatter glues, and the dynamics of particles during a phytoplankton bloom in a mesocosm study. Deep-Sea Res II 42(1):111-123

Decho AW (1990) Microbial exopolymer secretions in the ocean environments: their role(s) in food webs and marine processes. Oceanogr Mar Biol Annu Rev 28:73-153

Ducklow H (2000) Bacterial production and biomass in the oceans. In: Kirchman DL (ed) Microbial ecology of the oceans. Wiley-Liss, New York, p 85-120

Engel A (2000) The role of transparent exopolymer particles (TEP) in the increase in apparent particle stickiness (alpha) during the decline of a diatom bloom. J Plankton Res 22:485-497

Fuhrman J, Azam F (1980) Bacterioplankton secondary production estimates for coastal waters of British Colombia, Antarctica, and California. Appl Environ Microbiol 39: 1085-1095

Fukuda R, Ogawa H, Nagata T, Koike I (1998) Direct determination of carbon and nitrogen contents of natural bacterial assemblage in marine environments. Appl Environ Microbiol 64:3352-3358

Grossart HP, Simon M (1997) Formation of macroscopic organic aggregates (lake snow) in a large lake: the signif- 
icance of transparent exopolymer particles, phytoplankton, and zooplankton. Limnol Oceanogr 42:1651-1659

Grossart HP, Berman T, Simon M, Pohlmann K (1998) Occurrence and microbial dynamics of macroscopic organic aggregates (lake snow) in Lake Kinneret, Israel, in fall. Aquat Microb Ecol 14:59-67

Grossart HP, Riemann L, Azam F (2001) Bacterial motility in the sea and its ecological implications. Aquat Microb Ecol 25:247-258

Grossart HP, Czub G, Simon M (2006) Algae-bacteria interactions and their effects on aggregation and organic matter flux in the sea. Environ Microbiol 8(6):1974-1984

Harrison PJ, Waters RE, Taylor FJR (1980) A broad spectrum artificial seawater medium for coastal and open ocean phytoplankton. J Phycol 16:28-35

Holm-Hansen O, Lorenzen C, Holmes RW, Strickland JDH (1965) Fluorometric determination of chlorophyll. J Cons Int Explor Mer 30:3-15

Hong Y, Smith WO, White AM (1997) Studies on transparent exopolymer particles (TEP) produced in the Ross Sea (Antarctica) and by Phaeocystis antarctica (Prymnesiophyceae). J Phycol 33:368-376

Johnson BD, Kepkay PE (1992) Colloid transport and bacterial utilization of oceanic DOC. Deep-Sea Res 39(5): 855-869

Johnson BD, Zhou XL, Wangersky PJ (1986) Surface coagulation in seawater. Neth J Sea Res 20:201-210

Kiørboe T, Hansen JLS (1993) Phytoplankton aggregate formation: observations of patterns and mechanisms of cell sticking and the significance of exopolymeric material. J Plankton Res 15:993-1018

Kloareg G, Quatrano RS (1988) Structure of cell walls of marine algae and ecophysiological functions of the matrix polysaccharides. Oceanogr Mar Biol Annu Rev 26:259-315

Liu H, Buskey EJ (2000) Hypersalinity enhances the production of extracellular polymeric substance (EPS) in the Texas brown tide alga, Aureoumbra lagunensis (Pelagophyceae). J Phycol 36:71-77

Logan BE, Grossart HP, Simon M (1994) Direct observation of phytoplankton, TEP, and aggregates on polycarbonate filters using bright field microscopy. J Plankton Res 16: 1811-1815

Mari X, Kiørboe T (1996) Abundance, size distribution and bacterial colonization of transparent exopolymer particles (TEP) during spring in the Kattegat. J Plankton Res 18: 969-986

O'Melia DR, Tiller CL (1993) Physicochemical aggregation and deposition in aquatic environments. In: Buffle J, van Leeuwen HP (eds) Environmental particles, Vol 2. International Union of Pure and Applied Chemistry, Environmental Analytical and Physical Chemistry Series. Lewis Publishers, Ann Arbor, MI, p 353-385

Passow U (2000) Formation of transparent exopolymer particles, TEP, form dissolved precursor material. Mar Ecol Prog Ser 192:1-11

Passow U (2002a) Production of transparent exopolymer particles (TEP) by phyto- and bacterioplankton. Mar Ecol Prog Ser 236:1-12

Passow U (2002b) Transparent exopolymer particles (TEP) in aquatic environments. Prog Oceanogr 55:287-333

Passow U, Alldredge AL (1994) Distribution, size and bacterial colonization of transparent exopolymer particles (TEP) in the ocean. Mar Ecol Prog Ser 113:185-198
Passow U, Alldredge AL (1995a) Aggregation of a diatom bloom in a mesocosm: the role of transparent exopolymer particles (TEP). Deep-Sea Res II 42:99-109

Passow U, Alldredge AL (1995b) A dye-binding assay for the spectrophotometric measurement of transparent exopolymer particles (TEP). Limnol Oceanogr 40(7):1326-1335

Passow U, Shipe RF, Murray A, Pak DK, Brzezinski MA, Alldredge AL (2001) The origin of transparent exopolymer particles (TEP) and their role in the sedimentation of particulate matter. Cont Shelf Res 21(4):327-346

Penna A, Berluti S, Magnani M (1999) Influence of nutrient ratios on the in vitro extracellular polysaccharide production by marine diatoms from the Adriatic Sea. J Plankton Res 21:1681-1690

Prieto L, Ruiz J, Echevarria F, Garcia CM, Bartual A, Galvez JA, Corzo A, Macias D (2002) Scales and processes in the aggregation of diatom blooms: high time resolution and wide size range records in a mesocosm study. Deep-Sea Res I 49:1233-1253

Radic T, Radic J, Najdek M, Fuks D, Blaz'ina M (2003) Potential of the northern Adriatic bacterioplankton for the production of transparent exopolymer particles. Period Biol 105(4):381-387

Ramaiah N, Yoshikawa T, Furuya K (2001) Temporal variations in transparent exopolymer particles (TEP) associated with a diatom spring bloom in a subarctic ria in Japan. Mar Ecol Prog Ser 212:79-88

Riebesell U (1991) Particle aggregation during a diatom bloom. I. Physical aspects. Mar Ecol Prog Ser 69:271-280

Shibata A, Kogure K, Koike I, Ohwada K (1997) Formation of submicron colloidal particles from marine bacteria by viral infection. Mar Ecol Prog Ser 155:303-307

Stoderegger K, Herndl GJ (1998) Production and release of bacterial capsular material and its subsequent utilization by marine bacterioplankton. Limnol Oceanogr 43:877-884

Stoderegger KE, Herndl GJ (1999) Production of exopolymer particles by marine bacterioplankton under contrasting turbulence conditions. Mar Ecol Prog Ser 189:9-16

Strickland JDH, Parsons TR (1972) A practical handbook for seawater analysis. Bull Fish Res Board Can 167:310

Sutherland IW (1985) Biosynthesis and composition of gramnegative bacterial extracellular and wall polysaccharides. Annu Rev Microbiol 39:243-270

Suzuki R, Ishimaru T (1990) An improved method for the determination of phytoplankton chlorophyll using $\mathrm{N}, \mathrm{N}$ dimethylformamide. J Oceanogr Soc Jpn 46(4):190-194

Van Loosdrecht MCM, Lyklema J, Norde W, Zehnder AJB (1989) Bacterial adhesion: a physicochemical approach. Microb Ecol 17:1-15

Verdugo P, Alldredge AL, Azam F, Kirchman DL, Passow U, Santschi PH (2004) The oceanic gel phase: a bridge in the DOM-POM continuum. Mar Chem 92:67-85

Vrede K, Heldal M, Norland S, Bratbak G (2002) Elemental composition $(\mathrm{C}, \mathrm{N}, \mathrm{P})$ and cell volume of exponentially growing and nutrient-limited bacterioplankton. Appl Environ Microbiol 68:2965-2971

Zhou J, Mopper K, Passow U (1998) The role of surface-active carbohydrates in the formation of transparent exopolymer particles by bubble adsorption of seawater. Limnol Oceanogr 43:1860-1871

Zobell CE (1941) Studies on marine bacteria. I. The cultural requirements of heterotrophic aerobes. J Mar Res 4:42-75

Submitted: February 13, 2006; Accepted: October 10, 2006

Proofs received from author(s): December 29, 2006 